in healthy men. ${ }^{2}$ And even if these external conditions are comparable individual circumstances like changes in the fluid balance (day and night rhythm, menstrual cycle in the female, salt or liquorice consumption, oedema, and the effects of the drug itself, such as diarrhoea and diuresis) might influence the results. This introduces an explanation for the wide diversity in the reported data of effective serum levels of antibiotics, and an explanation why drug toxicity may occur, although the dose given remained constant after changes in the fluid balance and the patient's mobility (digitalis).

The relations of these postural changes in serum levels with effectual activity, elimination, and excretion are not known; they might be important for establishing doses and frequency of administration of a number of drugs.-We are, etc.,

C. B. M. Dalperup.

The Netherlands Institute

L. M. DALPERUP.

Wo Nutrition,

Wageningen,

The Netherlands.

REPERENCES

I Dalperup, L. M., F. Appl. Physiol., in press.

\section{Frozen Human Skin}

SIR,-Referring to leading article "Frozen Human Skin" (12 February, p. 374), as a result of our experience ${ }^{1}$ with a simple in vitro test of the viability of stored skin by the uptake of ${ }^{32} \mathrm{P}$ we find it possible to store skin at $-5^{\circ} \mathrm{C}$. to $-15^{\circ} \mathrm{C}$. without the necessity for the protection of the cells by glycerol.

It has been routine practice in this unit to store skin at the above temperatures, and we have been doing this since 1953 .

In clinical practice skin stored at $+4^{\circ} \mathrm{C}$. has really been of use for only seven to ten days. Skin stored at $-5^{\circ} \mathrm{C}$. to $-15^{\circ} \mathrm{C}$. is successfully used for periods up to three weeks after storage, and on the one occasion only when we tried it it had a successful take after ten weeks. The hope of storing at much deeper temperatures obviously would be of value.-I am, etc.,

$$
\text { J. ElLsworth LAiNg. }
$$

Plastic and Oral Surgery Centre,
Odstock Hospital, Odstock Hospital,
Salisbury, Wilts.

REFERENCE Proceedings of Second Radioisotope Conference,
vol. 1, edited by J. B. Johnstone, 1954.
London.

\section{Atropine Poisoning in Infancy}

SIR,-The danger of using atropine derivatives in children's respiratory infections is exemplified by a case seen recently at this hospital.

A 2 -month-old boy was seen in the casualty department with a history of catarrhal illness of eight days' duration, and high fever with prostration on the day of admission. He had been receiving Eumydrin drops (atropine methyl nitrate in $0.6 \%$ alcoholic solution), two drops (0.4 mg.) with each feed for a week.

On examination the child was cnmatose with a rectal temperature of $107.4^{\circ} \mathrm{F}$. $\left(41.9^{\circ} \mathrm{C}.\right)$, respiration rate of $70 /$ minute and a pulse rate of $160 /$ minute. His skin was pale and slightly cyanosed. No rash was seen.

Central nervous system examination revealed widely dilated pupils with only a slight reaction to light. Respiratory and cardiovascular systems were normal. No lymph nodes were palpable. The abdomen was distended and the colon laden with faeces.

There was no indication of a site of infection, and bacteriological studies were negative. The white blood cell count was 17,300, 53\% of which were neutrophil polymorphs. The cerebrospinal fluid was normal, and bloodculture showed no growth.

Cooling manæuvres quickly reduced his temperature to $100^{\circ} \mathrm{F}$. $\left(37.8^{\circ}\right.$ C.), but in spite of parenteral antibiotic therapy an intermittent fever of up to $101^{\circ} \mathrm{F}$. $\left(38.3^{\circ} \mathrm{C}\right.$.) persisted for five days. His general condition improved immediately the fever was reduced and normal feeding was started a few hours later.

Although the prescribed dosage was within the therapeutic range for atropine methyl nitrate, the fever and dilated pupils indicate a diagnosis of atropine-poisoning. Abdominal distension is a feature of this condition, especially in infants. Whether this is an example of idiosyncrasy or accidental overdosage remains uncertain.

In view of the danger of permanent damage to the central nervous system in extreme hyperpyrexia, caution should be exercised in the use of atropine and its derivatives, especially when, as in upper respiratory infections, there is a pre-existing cause of fever.

My thanks are due to Dr. T. E. Oppé, Director of the Paediatric Unit, St. Mary's Hospital, for permission to publish this case.

-I am, etc.,

\author{
Paddington Green Children's \\ Hospital, \\ London $W .2$.
}

\section{Farmer's Lung}

SIR,-I would like to endorse the timely warning given by Dr. J. McAllister Williams in his letter (15 January, p. 169) regarding the occurrence of cases of farmer's lung at this time of the year, especially as applying to Northern Ireland, where the condition is relatively common in certain districts.

A form of this disease which may be generally less well known than the tvpical syndrome can occur under certain circumstances in some individuals, usually females, who work with poultry in deep litter and who may be handling mouldy vegetable material in this connexion. In these the condition may develop very insidiously, sometimes over a period of years, and a serious and irreversible degree of lung damage with extensive bilateral pulmonary fibrosis may have supervened before the cause is finally recognized. The course and outcome in these patients closely resemble the pattern which evidently occurs in a comparable form of respiratory disease recently described by budgerigar fanciers and in whom, apparently, the same type of immunological mechanism is operating. These individuals, too, after periods of exposure to certain antigens derived from the avian source, also eventually develop restrictive pulmonary disease, Hargreave et al.,1 which affects susceptihle with reduced compliance and fibrosed "stiff lungs." This ultimate sequel would appear to be similar in all respects to that which occasionally occurs in the deep-litter workers as a late effect of farmer's lung.-I am, etc.,

$$
\begin{aligned}
& \begin{array}{l}
\text { Coleraine, } \\
\text { N. Ireland. }
\end{array} \\
& \text { C. T. B. AdAMs. }
\end{aligned}
$$

REFBRENCB 1 Hargreave, P. E., Pepys, J., Longbottom, J. L.,
and Wraith. D. G., Lancet, 1966, 1, 445.

\section{Abortion Law Reform}

SIR,-Mr. James Campbell (5 March, p 613) makes an important point when he states that the "instinctive repugnance" felt by many gynaecologists for the operation of abortion is a result of our "cultural conditioning." No doubt we could eventually be so conditioned that abortion, or the destruction of any other life too for that matter, gave no concern to our professional consciences.

It is at least debatable whether any such alteration, not to say lowering, of our ethical standards would benefit either our patients or ourselves. Our present relationship with our patients is, I believe, based upon their belief that we do, as a profession, have a repugnance for the taking of human life.

If this relationship is to be undermined, and doctors of the future " conditioned" otherwise than the present generation, then those dernanding such a change should think of their losses as well as any theoretical gain. -I am, etc.,

London N.W.7.

\section{R. W. TAYLOR.}

\section{Follow-up}

SIR,-In common with most other consultants I have been in the habit of seeing old patients, cured and not-so-cured, in the "old-patient clinic" or follow-up clinic, call it what you will. As one ages, so the number of old patients increases and so the clinic grows, in spite of earlier discharge, as experience grows.

After completing one more Saturday morning clinic I sat in a traffic jam wondering what the morning's work had achieved. Research and statistics need accurate follow-up, and it is rather nice to see old friends and to admire one's scars (or more frequently one's registrars' scars), but in a busy provincial hospital without a lot of assistance is followup by the consultant necessary? Certainly the consultant should be available for any referrals of old patients, but should he ask them to attend at regular intervals? How much follow-up can or should the general practitioner do? A carcinoma of the breast, once over the primary treatment, may of course recur at any time anywhere, and will not the patient go to the general practitioner with her bone pains or cerebral metastases? Regular attendance at hospital will not prevent the inevitable. Will not a gastrectomy case be picked up by his general practitioner with anaemia? Specific examples can be qunted ad nauseam. I write this letter in the hopes of stimulating comment. Perhaps an angry stream of abuse will come from general practitioners at the suggestion of increasing their already excessive burden; or 